\title{
The Influence of Employer's Behavior, Communication and Psychological Ownership in Promoting the Employee-Employer Relationship in the SMEs
}

\author{
Zuraina Dato Mansor, Siti Amifah Amdan \\ University Putra Malaysia, Selangor, Malaysia \\ drzurainadm@gmail.com
}

\begin{abstract}
Small and medium-sized enterprises (SMEs) can be deceptively complex organizations to manage due to a broad range of challenges, such as issues relating to owner-managers, as well as employees and the employment relationship (Mallett \& Wapshott, 2012). This study is conducted to study three factors, the behavior of the employer, the influence of communication and psychological ownership with relevant to promoting employee and employer relationship in the SMEs. Questionnaires were distributed to 150 employees of various SMEs in the Sri Serdang area of Selangor, Malaysia. The result was analyzed using the descriptive and correlation analysis.
\end{abstract}

Keywords: Employer employee relation, employer behavior, communication and psychological ownership

\section{Introduction}

Small and medium enterprises (SMEs) are considered the backbone of economic growth in all countries, and to prove this, Malaysia has developed the Ninth Malaysia Plan (2006-2010), where the government has designed a development plan to assist the SMEs to meet the new business challenges in the competitive global business environment. (Muhammad et al. 2010). In other literature, such as Saleh \& Ndubisi (2006), Samad (2007), and SMIDEC (2007), they noted the issues and challenges faced by SMEs such as barrier from global sourcing, low productivity, lack of managerial capabilities, lack of financing, difficulty in accessing management and technology, heavy regulatory burden and others. But, there is limited study that focuses on Human resource management (HRM) issues in this enterprise. Previous research on HRM and industrial relation (IR) mostly were conducted in the larger firms with the belief that they are more significance to the literature. In this paper, we explore employment relations in the case of SMEs. Small firms may use different management style but may probably put a high priority on human resources (Ritchie, 1993). Further, Ritchie (1993) also suggested that small medium firms (SMEs) often have little for formal control systems, and communication strategy is almost does not exist. This is justified based on the reason that owner always tried to facilitate open communication based on friendliness and informal atmosphere. The owners also tend to recruit people via network of family and friends and most of the time, they offer very limited training. While in another study, Wilkinson (1999) suggested that although research on HRM and IR in SMEs has emerged, studies in the employment issues still needs to be done.

SMEs are differing from larger firm in several important ways (Torres \& Julien, 2005). A previous research also stated that the culture of the relationship between the employee and employer also in most of the time are based on the owner' goals and desires (Jenning \& Beaver, 1997; Nadin \& Cassel, 2007) and it is normally fostered towards informal relationship and working practices that are generally flexible and quick to change and adapt (Gilman \& Edward, 2008). However, it is also suggested that relationship is this organization is important and should not be undervalued (Marlow and Patton, 1993). According to Marlow and Patton, 1993, 'employment relationships' in SMEs, should be focusing on how firms hire, manage, train, reward, handle disputes with and separate from employees as well as the broader relationship between employers and employees(Marlow and Patton, 1993). This is because such employee employer relationships can be influenced by the external factors and the unexpected environments (Kinnie et al., 1999). Any problem may arise that can result to employees experiencing tremendous changes. Thus, it is believed that a research should be carried out to examine how employee reacts and form relationship with their working environment. 
The objectives of this research are as follow:

- To study the influence of employer's behavior towards employee and its relationship in promoting employee and employer relationships in the SMEs type of business

- To study the influence of communication among employee and employer that influences their relationship in the SMEs business.

- To examine the relationship of psychological ownership and employee and employer relationship in the SMEs business

\section{The Importance of Employee Employer Relation}

Industries within SMEs are commonly associated with challenges which include among others, recession, barrier from global sourcing, low productivity, lack of managerial capabilities, and lack of financing, difficulty in accessing management, technology and heavy regulatory burden (Muhammad et al., 2010). With those constraints, maintaining healthy employee relations is not easy and need further attention in order to achieve the organizational positive performance. A study by Jarvis \& Rigby, (2012) suggested that a strong employee relation is required for high productivity and human satisfaction. However, strong employee relation does not only depends upon healthy and safe working environment, but also the level of involvement and commitment of all employees with managerial decision, incentives for employee motivation, and effective communication system. Employee relations generally deal with avoiding and resolving issues concerning individuals which might arise out of or influence the work scenario (Jarvis \& Rigby, 2012). Good employee relation signifies that employees should feel positive about their identity, their job as well as about being part of such organization. This notion is supported by a work by Sheehan (2013) who demonstrates the important of HRM to sustain the organization competitive advantage. Based on the theory of resource-based view of the firm, Sheehan (2013) suggested that employees should represent important sources of sustainable competitive advantage for SMEs thus the HRM policies should be implemented to bring positive impact on the firm's performance.

What will happen if there is no good relationship between employee and employer? Based on the Social exchange theory by Blau's (1964), the most influential conceptual paradigms for understanding workplace behaviors is a human interaction. Meanwhile, according to the Organizational support theory, Eisenberger et al. (1986) explained that support from the organization could reduce absenteeism and increased organization citizenship behavior and employee performance. Thus it is assumed that in order to promote a good relationship between employer and employees, organization need to put effort to enhance the ties based on the assumption the employees would feel obligated to return favorable attitudes and behaviors from management with good performance. This assumption is made based on the research by Randall (1990) who noted that working relationships which involved supervisory -subordinate relationship can affect commitment. Further, as stated by Luthans (2002), based on the positive psychology and organizational theories, which are merged in the positive organizational behavior (POB), has defined it as the study and application of positively oriented human resource strengths and psychological capacities that can be measured, developed, and effectively managed for performance improvement (Luthans, 2002). Prior to that Pierce, Kostova and Dirks $(2001,2003)$ based on studies in sociology, philosophy, human development and psychology, proposed the theory of psychological ownership which suggest a construct of relationship that is separate and distinct from the legal or equity ownership of an organization but instead will develop the relation of employee and employer.

In addition the study on employee and employer relationship also can be related to the theory of motivation. This is suggested because, it is believed that motivating is the management process that involve the act to influence behavior (Luthans, 1998). According to Luthans (1998) motivation is the process that arouses, energizes, directs, and sustains behavior and performance. It includes the factors that cause, channel, and sustain human behavior in a particular expected direction. While, according to Adeyemo (2000) motivation can be a tool that managers can use to drives people to work. Motivation also is assumed to promote a good employee and employer relation. In another point, the research by Robinson et al. (2004) has include the role of employee engagement which was defined as a positive attitude held by the employee towards the organization, to be one of the factor that can improve performance within the job. According to Robinson et al, in order to develop and nurture engagement, it requires a two-way relationship between employer and 
employee." This definition is in line with the Institute of Employment Studies definition that suggests employee engagement as the relationship between employer and employee and it has to be done by both sides (Markos and Sridevi, 2010). Based on the explanation above, the paper has proposed the H1 as;

H1: Employer behavior to the employees has a positive impact to employee employer relationship

Managing behavior and attitude will need a support of good communication from one manager to the next and from supervisor to the employees. This is because; managerial communication drives relationships and frames the attitudes and behaviors of employees in the workplace. Bahl (2000) suggested that effective communication is the lifeblood for organization and can reinforce the organization's vision, connects employees, fosters improvement, facilitates change, and drives business results. While a study by Dasgupta et al. (2013) explain that supervisors at the workplace should act as the agents for the organizations and be responsible to treat employees accordingly to the extend the employees would feel they receive a good support from organizations. Once employees assess the supervisory support as good and fair, they would act in accordance with a norm of reciprocity. This study suggests that an open, honest, and need-based communication can foster satisfaction and can increase commitment which also lead to minimize the issues of absenteeism and misconducts. Thus, the paper suggests $\mathrm{H} 2$ as;

\section{H2: Communication has a positive influence to employee employer relationship}

Prior research demonstrated that the ownership of employees was positively related to organizational performance (Rosen and Quarrey, 1987; Wagner and Rosen1985). Pierce et al. (2001) noted, three roots having a place, feelings of efficacy and self-identity - may contribute to psychological ownership of employees. Employees with psychological ownership regard targets as their extension, defend the organization voluntarily, and feel responsible for organizational goals, and the result is enhancement of organizational performance. According to Van Dyne and Pierce (2004) psychological ownership (PO) is an antecedent of organizational commitment. While Olckers, \& Du Plessis, (2012) in their studies has suggested that earlier researches on psychological ownership also has been look in the relation to commitment to organizations (VandeWalle, Van Dyne \&Kostova, 1995); greater job satisfaction (Pierce et. al., 1991; Van Dyne \& Pierce, 2004); better organizational performance (Van Dyne \& Pierce, 2004); more effort from employees to engage in organizational citizenship behaviors (Avey et al., 2009; VandeWalle et al., 1995; Van Dyne \& Pierce, 2004); more likely to remain with organizations (Avey et al., 2009).

\section{H3: Psychological Ownership has a positive impact to employee employer relationship}

\section{Theoretical Framework of the Research}

The conceptual framework that develops after reviewing all the related literatures:

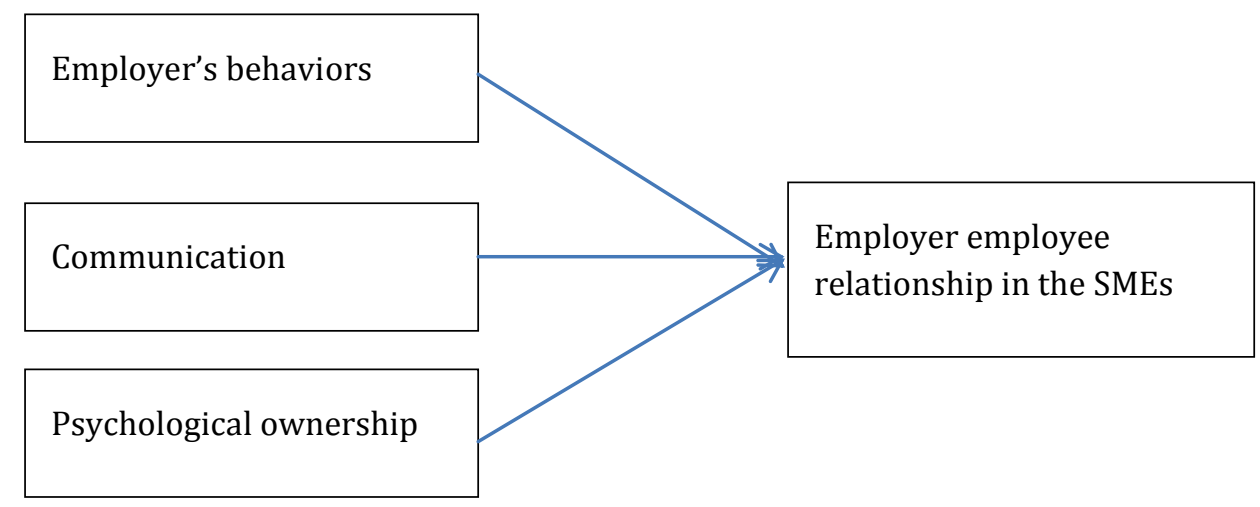

\section{Methodology}

The research used a closed-ended questions based on reason it is easier to manage, analyze and compare the meanings of the responses than open-ended questions. Questionnaire was designed according to the objective of this research. Questions that related to the factors were adapted from previous studies. The questionnaire was divided into two sections, Section A was constructed to study the influence and the existence of variables for this research, which are employer behaviors, communication and psychological ownership. For items to measure the influence of employers' behavior and the influence of communication, 
questions were drawn from Hatfield's (1977) and Huseman, Hatfield and Gatewood's (1978) typology of superior-subordinate communication. While for investigating the third item, which is the influence of psychological ownership questions were adopted and adapted from Van Dayne and Pierce (2004). In Section A, questions were asked using 6- point Likert- scales which ranging from strongly disagree to strongly agree. Section B, this section was aim to collect the respondent's personal information such as gender, year of birth, marital status, educational level, years of working in SMEs, and ethic group. The target respondents were chosen using convenient sampling among the employees working in small medium enterprise (SMEs) in area of Serdang, Selangor, Malaysia. The research has visited few SMEs premises in this area and then distributed the questionnaires by hand to the employees. A total of 180 questionnaires were distributed to the respondents at random during the survey. Out of that number, the researcher managed to collect 150. 30 questionnaires were dropped out from the analysis due to incomplete answers. Overall, the response rate was $83.3 \%$. The reliability was tested according the Cronbach's Alpha Index. The results were summarized in Table 1.

Table 1: Reliability Analysis Result

\begin{tabular}{lcc}
\hline Variables & Cronbach's Alpha & No. of Item \\
\hline Employee employer behavior & 0.782 & 7 \\
Communication & 0.834 & 8 \\
Psychological ownership & 0.700 & 5 \\
\hline
\end{tabular}

\section{Respondents' Demographic Profile}

Table 2: Respondents' Demographic Profile

\begin{tabular}{lll}
\hline Details & Frequency $(\mathbf{n}=\mathbf{1 5 0})$ & Percentage (\%) \\
\hline Gender & & \\
Male & 36 & 24 \\
Female & 114 & 76 \\
Age & & \\
20 below & 9 & 6 \\
$21-30$ & 138 & 92 \\
$31-40$ & 3 & 2 \\
Race & & \\
Malay & 133 & 88.7 \\
Chinesse & 4 & 2.7 \\
India & 11 & 7.3 \\
others & 2 & 1.3 \\
Marital Status & & \\
Bachelor & 139 & 92.7 \\
Married & 9 & 6 \\
Widow & 2 & 1.3 \\
Sector & & \\
Production & 120 & 80 \\
Manufacturing & 16 & 10.7 \\
Services & 14 & 9.3 \\
\hline
\end{tabular}

\section{Result and Findings}

Based on the questionnaires that have been developed for this research, the data was first analyzed using the descriptive analysis. For Section A, as mentioned earlier, questions 1 to 7 were measuring the strength of the employer's behavior. Based on the result, it has shown that the highest score of mean value is question number one; 'my manager supports my ability to deliver high standards of quality to my customers', which has a score mean value of 3.25. Next for questions in assessing the influence of communication, question number 12 and 15 have shown to be most influencing situations to promote employee and employer 
relationship. "My supervisor regularly talks with me about my progress' and 'My manager always gives his capacity to hear, evaluate, and respond to criticism and negative feelings from others" with mean value of 3.09 respectively. The highest mean value for questions under the item of psychological ownership scored only 2.85 with the question of 'This organization is part of my life'. It was assumed that employees in the selected SMEs have a feeling that they were part of the organization, but may be were unsure how long they would retain with the current company. Their life, based on the assumption, that majority of the respondents in this research were between 21 to 30, still have a long way to go. And, thus their relationship with the employer can be easily affected by 'dissatisfaction' especially when the management introduces a new thing that is out of their interest.

Table 3: Ranking of Importance for Factors that Influence the employees employer relationship

\begin{tabular}{lcc}
\hline Variable & Pearson Correlation & Ranks \\
\hline Employer's behavior & 0.40 & 1 \\
Communication & 0.351 & 2 \\
Psychological Ownership & 0.162 & 3 \\
\hline
\end{tabular}

The research also has performed a Pearson correlation analysis to identify the influence of the relationship of the tested variables. Table 3 indicates the importance of the three factors that influence employee employer relationship. Employer's behavior has the highest correlation to employee and employer relationship and was ranked as the most influential factor. The second factor was communication influence and the third influential factor was psychological ownership. Next the research has analyzed the data to test the hypotheses. With reference to Table 4, the H1, which is 'Employer behavior has a positive impact to employee employer relationship' has shown that the $\mathrm{p}<0.05$, thus suggest that the relationship is significant, hence H1 was supported and the strength association between the variable was considered as moderate $(r=0.400)$.

Table 4: Correlation between employer's behaviors and employee and employer relationship

\begin{tabular}{llcc}
\hline & EE RS & LBEHAV \\
\hline EE RS & Pearson correlation & 1 & $.400^{* *}$ \\
& Sig. (2 tailed & & .000 \\
& $\mathrm{~N}$ & 150 & 150 \\
LBEHAV & Pearson Correlation & $400^{* *}$ & \\
& Sig, (2 tailed) & .000 & 150 \\
& $\mathrm{~N}$ & 150 & \\
\hline
\end{tabular}

** Correlation is significant at the 0.01 level (2-tailed).

According to the result as shown in the Table 5, the correlation between the communication and employee and employer relationship indicated it as significant where $\mathrm{p}<0.05$ (at 0.00 ), thus $\mathrm{H} 2$ was supported. The strength of the association between variable was slightly low $(r=0.351)$. This suggests that communication influence has a significant significantly low influence on the employee employer relationship.

Table 5: Correlation between the Communication and employee employer relationship

\begin{tabular}{llcc}
\hline & EE RS & COMMUNICATION \\
\hline EE RS & Pearson correlation & 1 & $351^{*}$ \\
& Sig. (2 tailed) & & .000 \\
COMM & Pearson Correla. & 150 & 150 \\
& Sig, (2 tailed & $351^{* *}$ & 1 \\
$\mathrm{~N}$ & & .000 \\
& 150 & 150 \\
\hline
\end{tabular}

** Correlation is significant at the 0.01 level (2-tailed)

Further, the result has shown that the correlation between Psychological Ownership and Employee Employer relationship, as shown in Table 6, indicated that $p$ value also significant $(p<0.05)$, thus we accept H3. The $r$ value was 0.047 suggesting that the variable, psychological ownership, have a weak strength of association with employee employer relationship, thus the research assumed that there was low feeling of ownership 
among the employees towards their organization and it is unlikely to affect the employer and employee relationship.

\section{Table 6: Correlation between Psychological Ownership and Employee Employer relationship}

\begin{tabular}{llc}
\hline & EE_R & POWNERSHIP \\
\hline EE_R Pearson Correlation & 1 & .162 \\
Sig. (2-tailed & & .047 \\
$\mathrm{~N}$ & 150 & 150 \\
POWNERSHIP Pearson Correlation & .162 & 1 \\
Sig. (2-tailed) & .047 & \\
$\mathrm{~N}$ & 150 & 150 \\
\hline
\end{tabular}

* Correlation is significant at the 0.05 level (2-tailed).

Discussion: Employer's behavior was found having a significant and strong and positive relationship with employee employer relationship and ranked at 1st which had the highest importance among the factors with a mean score of 0.782. This result is supported by the studies by Wright \& Cropanzano, (2004) who discovered that behaviors can affect the employee employer relationship in which they suggested that happy workers are productive workers. Every organization is responsible to ensure they have effective channels of communication. Our result has shown that communication can influences employee employer relationship. This findings parallel to the previous researches which suggested that open communication is one of the keys to the successful development of mutually beneficial psychological contracts (Rodwell, Kienzle \& Shadur, 1998). Clear and honest discussion will facilitate understanding of expectations, organizational culture, and promote the employee employer relationship. According to prior research, psychological ownership may strengthen the relations between employers and employees and make employees produce extra-role and voluntary behaviors which foster organizational performance via the psychological contract that exists between employers and employees. This study also has found a positive correlation between psychological ownership and employee employer relationship. In past research, psychological ownership has not previously been associated widely, but it can be conceptualized as a positive psychological resource (see the ownership of employees was positively related to organizational performance (Rosen and Quarrey, 1987).

\section{Conclusion}

This research aims to study the factors that influence how employer behavior, communication and psychological ownership affect the employer and employee relationship. The study has found that there was a positive relationship between employer's behavior, communication and psychological ownership in promoting employee employer relationship. Employer's behavior was found to be the top influence to employee employer relationship, while communication was second and third was psychological ownership. In conclusion, we recommend that SME to enhance the strategies, policies and procedures that are prolong and sustaining the good relationship between employer and employees by focusing on honesty and open policy. This is because when in many cases SME have a quite small number of employees; it is belief that there is no reason to strengthen the relationship. By the way, having a good employee relation can minimize misunderstandings that may result violations.

\section{References}

Adeyemo, D. A. (2000). Job involvement, career commitment, organizational commitment and job satisfaction of the Nigerian police. A multiple regression analysis. Journal of Advance Studies in Educational Management, 5(6), 35-41

Avey, J. B., Avolio, B. J., Crossley, C. D. \& Luthans, F. (2009). Psychological ownership: Theoretical extensions, measurement and relation to work outcomes. Journal of Organizational Behavior, 30, 173-191. http://dx.doi.org/10.1002/job.583

Blau, P. M. (1964). Exchange and Power in Social Life, Wiley, New York, NY.

Bahl, T. (2000). Learning to love ourselves, The Sunday Tribune Spectrum, 23 April, available at: www.tribuneindia.com/2000/20000423/spectrum/option.htm 
Dasgupta, S. A., Damodar, S. \& Seema, S. (2013). Impact of managerial communication styles on employees' attitudes and behaviors. Employee Relations, 35(2), 173 - 199

Eisenberger, R., Huntington, R., Hutchison, S. \& Sowa, D. (1986). Perceived Organizational support. Journal of Applied Psychology, 71, 500-507.

Gilman, M. W. \& Edwards, P. K. (2008). Testing a framework of the organization of small firms: Fast-growth, high-tech SMEs. International Small Business Journal, 26(5), 531-558.

Hatfield, J. D. (1977). Categories for analyzing superior-subordinate interactions. Paper presented at the $37^{\text {th }}$ meeting of the Academy of Management, Kissimmee, Florida.

Huseman, R. C., Hatfield, J. D. \& Gatewood, R. D. (1978). A conceptual framework for analyzing the communication- productivity relationship. Paper presented at the 38th meeting of the Academy of Management, San Francisco, p78.

Jarvis, R. \& Rigby, M. (2012). The provision of human resources and employment advice to small and medium-sized enterprises: The role of small and medium-sized practices of accountants. International Small Business Journal, 30(8), 944-956

Jennings, P. \& Beaver, G. (1997). The performance and competitive advantage of small firms: A management perspective. International Small Business Journal, 15(2), 63-75.

Kinnie, N., Purcell, J., Hutchinson, S., Terry, M., Collinson, M. \& Scarbrough, H. (1999). Employment relations in SMEs: Market-driven or customer-shaped? Employee Relations, 21(3), 218-235

Luthans, F. (1998). Organizational Behavior. 8th ed. Boston: Irwin McGraw-Hill.

Luthans, F. (2002). Positive organizational behavior: Developing and managing psychological strengths. Academy of Management Executive, 16, 57-72

Maimunah, A. (2010). Malaysian Industrial Relations \& Employment Law, Mcgraw hill Publisher, Kula Lumpur, Malaysia

Mallett, 0. \& Wapshott, R. (2012). Informality and employment relationships in small firms: Humour, ambiguity and straight-talking. British Journal of Management, Available Early View, DOI 10.1111/j.1467-8551.2012.00836.x retrieved on 20 Jan 2015 from http://isb.sagepub.com/site/Virtual_Special_Issues/Employment_Relationships_Intro.pdf

Marlow, S. \& Patton, D. (1993). Managing the employment relationship in the small firm: Possibilities for human resource management. International Small Business Journal, 11(4), 57-64

Markos, S. \& Sridevi, M. S. (2010). Employee Engagement: The Key to Improving Performance. International Journal of Business and Management, 5(12); December 2010 retrieved from http://www.myopinionatbesix.com/BesixSurvey/media/Besix-Survey/pdf/4.-Employeeengagement-The-Key-to-Improving-Performance.pdf

Muhammad, M. Z., Char, A. K., Yasoa, M. R. \& Hassan, Z. (2010). Small and Medium Enterprises (SMEs) Competing in the Global Business Environment: A Case of Malaysia. International Business Research, $3(1)$.

Nadin, S. \& Cassell, C. (2007). New deal for old? Exploring the psychological contract in a small firm environment. International Small Business Journal, 25(4), 417-443

Olckers, C. \& Du Plessis, Y. (2012). The role of psychological ownership in retaining talent: A systematic literature review. SA Journal of Human Resource Management/SA TydskrifvirMenslikehulpbronbestuur, 10(2), Art.No. 415, 18 pages. Retrieved from http://dx.doi.org/10.4102/sajhrm.v10i2.415

Pierce, J. L., Kostova, T. \& Dirks, K. T. (2001). Towards a theory of psychological ownership in organizations. Academy of Management Review, 26(2), 298-310. Retrieved n.d., from http://www.jstor.org/stable/259124

Pierce, J. L., Kostova, T. \& Dirks, K.T. (2003). The state of psychological ownership: Integrating and extending a century of research. Review of General Psychology, 7(1), 84-107.

Randall, D. (1990). The consequences of organizational commitment: Methodological investigation. Journal of Organizational Behavior, 11, 361-378.

Ritchie, J. (1993). Strategies for human resource management: challenges in smaller and entrepreneurial organizations, in Harrison, R. (Ed.), Human Resource Management, Addison-Wesley, Wokingham, pp. 111-35.

Robinson, D., Perryman, S. \& Hayday, S. (2004). The Drivers of Employee Engagement Report 408, Institute for Employment Studies, UK 
Rodwell, J. J., Kienzle, R. \& Shadur, M. A. (1998). The relationships among work-related perceptions, Employee attitudes, and employee performance: The integral role of communication. Human Resource Management, 37(3/4), 277-293

Rogers, B. A. (2002). Funding of SMEs: Sourcing of Funds and Problems, ICAN journal. Nigerian Accountant, 35(1) January/March.

Rosen, C. M. \& Quarrey, M. (1987). How Well Is Employee Ownership Working? Harvard Business Review, 65, 126-132

Saleh, A. S. \& Ndubisi, N. O. (2006). SME development in Malaysia: domestic and global challenges. [On-line]. Available: http://www.uow.edu.au/commerce/econ/wpapers.html

Samad, N. A. (2007). Positioning Malaysian SMEs in the global. Proceedings of PersidanganKebangsaan IKS 2007, Kota Kinabalu: Universiti Utara Malaysia. Schein, E. H. (1980). Organizational psychology. Englewood Cliffs, NJ: Prentice Hall.

Sheehan, M. (2013) Human resource management and performance: Evidence from small and medium-sized firms. International Small Business Journal, Available Online First. DOI: $10.1177 / 0266242612465454$

SMIDEC. (2007). SME development programme. [On-line]. Available: http://www.smidec.gov.my/detailpage.jsp?section=defsme\&level=1.

Torrès, 0. \& Julien, P. A. (2005). Specificity and denaturing of small business. International Small Business Journal, 23(4), 355-377

Wagner, I. \& Rosen, C. (1985). Employee Ownership: Its Effects on Corporate Performance. Employee Relations Today, 12, 73-79.

Wagner, S. H., Parker, C. P. \& Christianson, N. D. (2003). Employees that think and act like owners: Effects of ownership beliefs and behaviors on organizational effectiveness. Personnel Psychology, 56, 847871. http://dx.doi.org/10.1111/j.1744-6570.2003.

Wright, T. A. \& Cropanzano, R. (2004). The role of psychological well-being in job performance: A fresh look at an age-old quest. Organizational Dynamics, 33, 338- 351.

Wilkinson, A. (1999). Employment relations in SMEs. Employee Relations, 21(3), 206 - 217

Van Dyne, L. \& Pierce, J. L. (2004). Psychological Ownership and Feelings of Possession: Three Field Studies Predicting Employee Attitudes and Organizational Citizenship Behavior. Journal of Organizational Behavior, 25, 439-459.

VandeWalle, D., Van Dyne, L. \& Kostova, T. (1995). Psychological ownership: An empirical examination of its consequences. Group and Organization Management, 20(2), 210-226. 